\title{
GERAÇÃO DE ENERGIA A PARTIR DE RESÍDUOS URBANOS: COLETA E TRATAMENTO, EXEMPLOS DO NORTE DA ITÁLIA
}

\author{
Giovanni Maria Arrigone, PhD. (SENAI / CTAI); Cristine do Nasci- \\ mento Mutti, PhD. (UFSC); Paulo César Machado Ferroli, Dr. Eng. \\ (UFSC); Lisiane Ilha Librelotto, Dra. Eng. (UFSC)
}

\author{
PALAVRAS CHAVE \\ Resíduos Urbanos, Energia, Coleta Seletiva, Incinerador \\ KEY WORDS \\ Municipal Waste, Energy, Selective Collection, Incinerator
}

\begin{abstract}
RESUMO
O problema da eliminação e armazenamento de resíduos urbanos é amplamente discutido por entidades privadas e governamentais hoje em dia. Uma das soluções existentes é a possibilidade de combinar coleta seletiva com incineradores de resíduos para a produção de energia. Neste artigo são apresentados dados obtidos em um estudo sobre uma firma que gerencia a coleta seletiva e racional de resíduos urbanos (C.S.R. - Consorzio Servizi Rifiuti e ASMT - Azienda Servizi Municipalizzati Tortonesi de Tortona, província de Alessandria) e um incinerador de resíduos (termo-utilizador ou TU) de concepção avançada localizado na cidade de Brescia na Itália. O TU utiliza resíduos urbanos não recicláveis para produzir, através combustão, energia térmica que pode ser utilizada diretamente como forma de aquecimento (teleriscaldamento) ou convertida em energia elétrica.
\end{abstract}

\section{ABSTRACT}

The problem of disposal and storage of municipal waste is, nowadays, widely discussed by private and government entities. One of the existing solutions is the ability to combine selective collection with waste incinerators to produce energy. This article presents data from a study of companies that manage selective and efficient collection of municipal waste (CSR - Consorzio Servizi Rifiuti and ASMT - Azienda Servizi Municipalizzati Tortonesi of Tortona, Alessandria province) and a waste incinerator (thermo user or TU) of advanced design in the city of Brescia in Italy. The TU uses non-recyclable municipal waste to produce, through combustion, thermal energy that can be used directly as a means of heating (teleriscaldamento) or converted into electricity. 


\section{INTRODUÇÃO}

A coleta e disposição segura dos resíduos urbanos estão virando o foco principal de discussões hoje em dia quando se enfrentam temáticas urbanas em função do aumento da quantidade e variedade dos resíduos produzidos, e conseqüente dificuldade de eliminação ou armazenamento seguro para a saúde humana. A reciclagem e o reuso de materiais originados dos resíduos urbanos parece uma das possíveis diretrizes na tendência a uma redução do volume dos resíduos através de uma coleta seletiva e inteligente dos resíduos envolvendo não somente as empresas encarregadas da coleta, mas também o cidadão, que torna-se ator principal no processo.

Uma das componentes mais interessantes deste processo de envolvimento do cidadão na gestão inteligente dos resíduos é a idéia que o lixo simplesmente não desaparece depois de jogado na lixeira, ele deve ser depositado em algum lugar.

O cidadão pode ser envolvido no processo através de várias etapas:

1)Conscientização: através de panfletos, campanhas de propagandas nos mídias e nas escolas, o problema da coleta e do armazenamento seguro de resíduos urbanos é comunicado e compartilhado gerando uma compreensão do problema e das possíveis conseqüências negativas sobre a saúde;

2)Gratificação: o cidadão/cliente privado deve poder ter um ganho (financeiro, por exemplo, mas também moral ou ético) do seu envolvimento no processo; um incentivo real e palpável é um dos requisitos mais energético no alcançar uma participação ativa e consciente no processo;

3)Informação e retorno (feed-back): o privado deve poder "ver" os resultados do seu esforço para poder quantificar o valor dos seus esforços e manter um alto nível de envolvimento no processo (satisfação e orgulho).

No Brasil a seleção dos resíduos é normalmente deixada à boa vontade do cidadão privado, que utiliza para isto recipientes diferenciados fornecidos no prédio, ou à habilidade do catador de lixo que seleciona os materiais que depois vende para lucro pessoal. A boa vontade do cidadão entra muitas vezes em conflito com o trabalho de selecionar as enormes quantidades de resíduos produzidos.

Como estímulo, em alguns casos na Europa foi introduzida uma técnica de retorno "quase-financeiro" onde máquinas do tipo distribuidoras, permitem ao cidadão de depositar embalagens, garrafas e potes recebendo em troca cupons que podem ser usados em lojas para obter descontos ou reduções de preço (isto pode gerar uma sensação de satisfação moral em gastar "dinheiro da reciclagem" que proporciona um valor real ao trabalho a pessoa em selecionar o lixo - ver figura 1).

Figura 1: Estação automática para a recolha diferenciada de garrafas de plástico e latas na cidade de Alessandria (IT). Bonus de 2 centavos para cada peça.

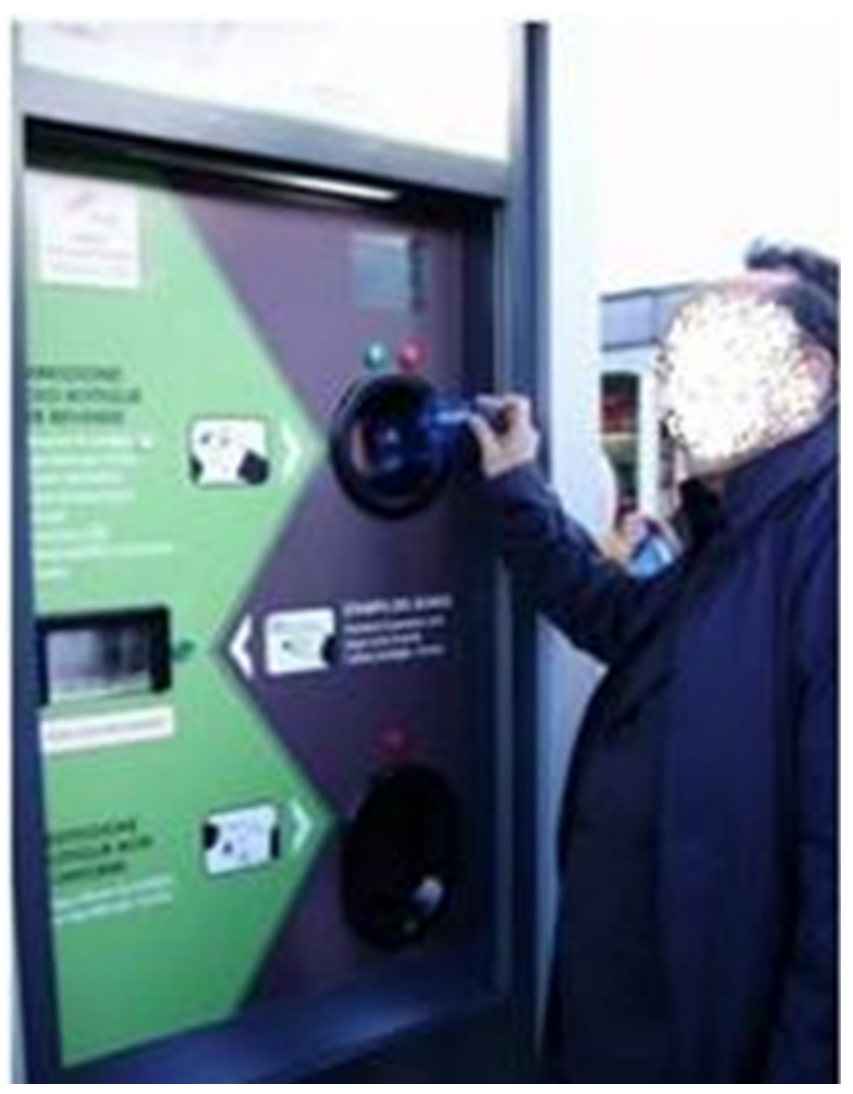

Fonte: Eco Dalle Città,( 2015.)

Uma alternativa seria a introdução de um processo de coleta seletiva forçada onde o cidadão deve entregar o lixo selecionado de acordo com uma tabela de dias específicos; por exemplo, onde segunda é recolhido somente papel 
(jornais, embalagens), terça somente plástico (embalagens, garrafas), terça somente vidro, etc. Isto acontece, por exemplo, na Itália onde o lixo previamente selecionado pode ser depositado em lixeiras diferenciadas (por forma e cor) nas lixeiras nas ruas. O cidadão também recebe recipientes menores para ter em casa os quais serão esvaziados pela empresa de coleta do lixo em dias pré-estabelecidos (ver Figura 2).

Figura 2: Recipientes para a coleta diferenciada do lixo na rua (esquerda) e individuais (direita).
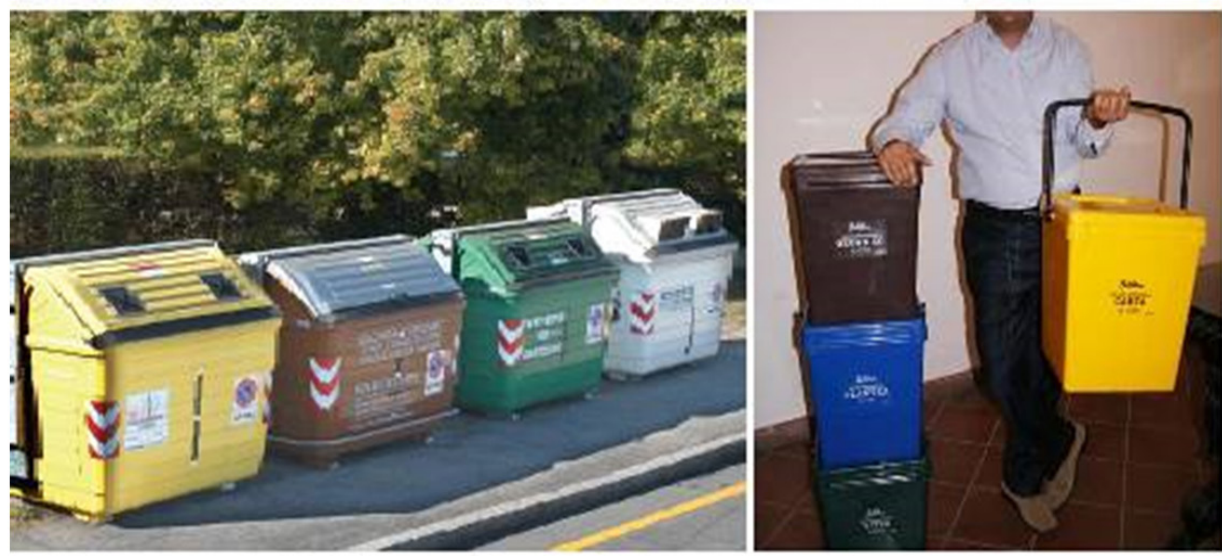

Fonte: Autores.

A coleta seletiva permite também de selecionar resíduos não recicláveis ou reutilizáveis que mesmo assim podem ainda ter uma função útil na produção de energia (térmica, por exemplo) em vez de ocupar espaço em aterros ou em outros lugares não aptos para o armazenamento (o mar, por exemplo).

Os focos do estudo foram dois: investigar um sistema exemplar de coleta seletiva e tratamento de resíduos que resulta em alto percentual de coleta seletiva e geração de energia por biogás - o caso de Tortona; e investigar coleta seletiva com resultado potencializado: a geração de calor e energia através da incineração de resíduos não recicláveis: o caso do TU da Brescia. O trabalho aqui apresentado tem como propósito relatar estas duas experiências exemplares de coleta seletiva e geração de energia, apresentando a estrutura, organização, procedimentos e resultados destas atividades.

\section{COLETA SELETIVA, BIOGÁS E GERAÇÃO DE ENERGIA}

\subsection{ATERROS SANITÁRIOS}

Para a gestão de resíduos urbanos, as alternativas mais freqüentes são o armazenamento em grande aterros/ lixões (landfilling), afundamento no mar ou reciclagem total. As primeiras duas não parecem ser opções sustentáveis.

Barbosa (2014) diz que mais da metade dos municípios do país ainda enterram seus lixos em buracos sem o mínimo de proteção necessária para evitar contaminação do meio ambiente, colocando a saúde da população em risco.

No Brasil a Lei dos resíduos sólidos - Lei 12.305, denominada de Lei da Política Nacional de Resíduos Sólidos, entrada em vigor em 3 de agosto de 2010 (BRASIL, 2010) determina que todos os lixões do país deviam ser fechados até o dia 2 de agosto de 2014 e que os resíduos sem possibilidade de reciclagem deveriam ser encaminhados para um aterro sanitário .

O prazo de fechamento dos lixões não pode ser cumprido e vários novos prazos foram decididos (com prolongamentos de prazo de até oito anos).

A falta de comprometimento das autoridades competentes ou as dificuldades de tipo econômico não são os únicos fatores que fazem a diferença. "Dos cerca de 2500 municípios brasileiros que ainda possuem lixão (de um total de 5.570), 45\% estão concentrados no Norte, Nordeste e Centro-Oeste. Em muitas regiões, tem-se um problema de distância e de isolamento, há lugares onde só se chega de barco. Ariovaldo Caodaglio, presidente do Sindicato das Empresas de Limpeza Urbana no Estado de São Paulo (Selur) pontua a dificuldade de transportar resíduo neste caso.

Em caso de uso de aterros, cuidados de- 
vem ser tomados. Os aterros devem ser construídos em maneira a prevenir infiltrações de líquidos contaminantes (chorume), originados dos resíduos, no lençol freático que fornece água para uso humano. Isto pode ser um grande problema para saúde humana (SISINNO, MOREIRA, 1996).

O aterro uma vez cheio será coberto, tornando-se uma superfície de difícil utilização em quanto sujeita a variações de altura/nível (já que no interior os resíduos se transformam, decompondo-se e mudando de volume) e a emissões dos produtos da transformação dos resíduos no seu interior (como, por exemplo, chorume e metano, $\mathrm{CH}_{4^{\prime}}$ um dos gases mais envolvidos no efeito estufa).

Normalmente os aterros são difíceis de fiscalizar e controlar em termos de:

1)Adequação às normas na construção da estrutura do aterro e conseqüente possibilidade de infiltrações no subsolo devida à má execução ou escolha de lugar geologicamente não idôneo;

2)Material depositado no aterro que pode produzir um perigo em termos de contaminação em liberar gases perigosos ou tóxicos ou radiações ou outros tipos de poluentes.

$\mathrm{O}$ afundamento no mar não parece mais uma alternativa viável, por vários motivos como a contaminação do ambiente (poluição) e a criação de situações anômalas e difíceis de controlar como a formação de "ilhas de fragmentos de plástico" em áreas de confluência de correntes marinhas como o Pacific Trash Vortex, ou Vórtice de Lixo do Pacifico (EPA, 2011).

A reciclagem total dos resíduos é uma realidade ainda longe de ser alcançada. Muitos resíduos ainda não têm como ser reaproveitados em maneira eficiente e economicamente viável. Por exemplo, lâmpadas, acrílicos, papel celofane, espuma, Espuma Vinílica Acetinada (EVA) e Isopor: este último material pode ser reciclado, porém, muitas empresas que trabalham com reciclagem rejeitam o isopor em função do baixo retorno financeiro que representa. A reciclagem também acontece com uso de recursos energéticos e processos químicos que podem ter um impacto sobre o meio ambiente

Uma das vantagens da coleta seletiva é a possibilidade de utilizar aterros em maneira eficiente e não perigosa.

\subsection{GERAÇÃO DE ENERGIA}

A possibilidade de transformar o aterro em um elemento desfrutável economicamente para produzir energia em vez de um perigo ou inconveniente pode produzir uma nova tendência em que o aterro vira necessariamente controlado para produzir os melhores resultados, uma vantagem, em vez de um problema (figura 3).

Figura 3: Seqüência de captação de biogás de aterros

\section{Captura do metano de aterros}

Poços de captura

A captura do metano dos aterros (Figura 3), é uma realidade que pode ser utilizada em lugares com dificuldade em abastecimento energético ou como suporte na geração normal. O gás produzido da decomposição dos resíduos (1) é captado (2) por poços de coleta que são usados para enviar o gás às usinas de transformação (3).

Uma segunda possibilidade para a conversão de resíduos em energia é a queima de resíduos previamente selecionados através da coleta seletiva em um incinerador. 
alternativa viável por apresentar dois grandes fatores positivos:

1) A combustão reduz o volume de resíduos (em 90-95\%);

2)A combustão produz também calor que adequadamente desfrutado pode gerar energia. (Comune di Brescia 2008-2010):

Mas a simples menção de incineradores pode gerar rejeição como tecnologia, em função das emissões geradas. Johnke (1998) relata em maneira abrangente as emissões de um incinerador explicando que a incineração de resíduos urbanos envolve a geração de emissões relevantes para o clima. Estes são principalmente emissões de $\mathrm{CO}_{2}$ (dióxido de carbono), bem como de $\mathrm{N}_{2} \mathrm{O}$ (óxido nitroso), $\mathrm{NO}_{x}$ (óxidos de azoto), $\mathrm{NH}_{3}$ (amónia) e $\mathrm{C}$ orgânico, medido como carbono total. $\mathrm{CH}_{4}$ (metano) não é gerado na incineração de resíduos durante a operação normal de modo que $\mathrm{CH}_{4}$ em termos quantitativos, não é para ser-visto como relevante para o clima. $\mathrm{CO}_{2}$ constitui a principal emissão relevante sobre o clima da incineração de resíduos e é consideravelmente maior, por pelo menos 102, do que os outros gases.

Muitos artigos apontam para o desenvolvimento que a tecnologia dos incineradores teve dos anos 90 até hoje em particular sobre o nível alcançado no monitoramento e abatimento das emissões em conjunto com a melhoria no desempenho energético (PORTEOUS, 2001).

A aceitação dos incineradores e da prática de eliminação dos resíduos urbanos contrasta fortemente com o sentimento de adversidade do publico alimentada pela ansiedade sobre os efeitos sobre a saúde das emissões. Ao considerar a toxicidade das emissões de processos industriais, é óbvio que efeitos nocivos são possíveis, mas um método simples para explicar o tamanho do risco global tem sido difícil de achar. A única maneira que pode mostrar corretamente quanto grande seja o risco de dano a saúde de fato é a comparação com outras exposições ou riscos mais conhecidos. Por exemplo, o risco de morrer de emissões do incinerador é, em geral, 500 vezes menor do que o risco de morrer em um acidente de estrada (ROBERTS, CHEN, 2006).
Pode-se condensar as vantagens e desvantagens dos dois grandes métodos de tratamento dos resíduos na Tabela 1 (PARO et al., 2008)

\section{MÉTODO}

Como já destacado, os focos do estudo foram dois: investigar um sistema exemplar de coleta seletiva e tratamento de resíduos que resulta em alto percentual de coleta seletiva e geração de energia por biogás - o caso de Tortona; e investigar coleta seletiva com resultado potencializado: a geração de calor e energia através da incineração de resíduos não recicláveis: o caso do TU da Brescia.

O método utilizado neste estudo seguiu cinco fases distintas, mas seqüenciais:

I. Procedimento inicial de definição do foco da pesquisa e das problemáticas envolvidas.

II. Planejamento das visitas e da coleta das informações relevantes;

III. Pesquisa bibliográfica e fundamentação teórica;

IV. Elaboração do roteiro de perguntas para entrevistas e esclarecimentos sobre os processos e técnicas envolvidas;

VI. Realização das visitas, entrevistas e coleta de material documental;

V. Análise de documentos.

As entrevistas foram estruturadas nos seguintes tópicos:

Para a visita ao termoutilizador: (a) Diretor: composição da empresa; gestão dos resíduos; geração de calor; normativas seguidas; emissões de gases; processo de projeto, construção e fundação do TU; dificuldades encontradas (técnicas e sociais); sistema de análise nas na chaminé / resultados e impacto; destino dos resíduos da incineração; funcionamento do sistema de aquecimento à distância; funcionamento do sistema de geração de eletricidade; adequação do sistema para menor alcance, como bairros, grandes condomínios ou centros comerciais; (b) Vice-chefe de operações: forma de gestão pela empresa; características dos resíduos recebidos e tratados; forma de tratamento de resíduos, 
Tabela 1 - Vantagens e desvantagens de aterros sanitários e incineração

\begin{tabular}{|c|c|}
\hline Aterros Sanitários & Usina de Incineração \\
\hline Vantagens & Vantagens \\
\hline $\begin{array}{l}\text { - Recebem os RSU praticamente da maneira } \\
\text { como são recolhidos, através das estações de } \\
\text { transbordo; } \\
\text { - Dispõem o lixo de maneira adequada } \\
\text { ambientalmente; } \\
\text { - Geram biogás que pode ser capturado e } \\
\text { aproveitado; } \\
\text { - Exige a captura e o tratamento do "chorume"; } \\
\text { - Emissão de carbono é distribuída no tempo, } \\
\text { uma vez que o ciclo de vida de um aterro é de } \\
\text { em média } 40 \text { anos. }\end{array}$ & $\begin{array}{l}\text { - Reduz } 70 \text { - } 75 \% \text { da massa e cerca de } 90 \% \text { do } \\
\text { volume dos RSU; } \\
\text { - Incentiva a triagem e reciclagem de materiais, } \\
\text { uma vez que alguns deles não podem ser } \\
\text { inseridos no incinerador; } \\
\text { - Não exige grandes áreas como o aterro, } \\
\text { apenas a área da usina; } \\
\text { - Inexiste o "chorume"; } \\
\text { - Elimina emissões de } \mathrm{CH}_{4} \text {; } \\
\text { - Gera significativa quantidade de energia } \\
\text { elétrica, reduzindo a queima de combustíveis } \\
\text { fósseis em termelétricas. }\end{array}$ \\
\hline Desvantagens & Desva \\
\hline $\begin{array}{l}\text { - Exige grandes áreas para implantação; } \\
\text { - Impossibilita o uso da área por muitos anos } \\
\text { - } \text { - Exós o fechamento do aterro; } \\
\text { - Provoca grande movimentação de terra e } \\
\text { resíduos; } \\
\text { - Gera menor quantidade de energia elétrica ao } \\
\text { longo do tempo; } \\
\text { - Após capacidade esgotada, exige ainda } \\
\text { cuidados e manutenção por pelo menos } 30 \\
\text { anos. }\end{array}$ & $\begin{array}{l}\text { - Necessita tratamento do lixo urbano para } \\
\text { retirada de metais, vidro, redução de resíduos } \\
\text { de alimentos e umidade, antes do envio para } \\
\text { incineração; } \\
\text { - Emite grande quantidade de } \mathrm{CO}_{2^{\prime}} \text { mas tais } \\
\text { emissões podem ser compensadas com as } \\
\text { respectivas reduções nas termelétricas; } \\
\text { - Pode emitir poluentes como } \mathrm{CO}, \mathrm{SO} \text {, NOx, } \\
\text { material particulado, dioxinas e furanos caso } \\
\text { medidas mitigadoras não sejam tomadas. }\end{array}$ \\
\hline
\end{tabular}

sistema de análise nas na chaminé / resultados; destino dos resíduos da incineração; funcionamento: características operacionais de todos os sistemas envolvidos (com grande detalhamento); características do pessoal empregado.

Para o Consorzio Servizi Rifiuti as entrevistas realizadas foram sobre tópicos gerais da gestão dos resíduos urbanos.

\section{RESULTADOS DAS VISITAS E DADOS OB- TIDOS}

\subsection{C.S.R. - CONSORZIO SERVIZI RIFIUTI}

Foi feita uma visita ao Consorzio Servizi Rifiuti, Consórcio que gerencia os serviços mu- nicipais como água, transportes e resíduos da província de Alessandria (na região Piemonte, na Itália). O foco da visita foi o tratamento de resíduos, para conhecimento do sistema de coleta e tratamento de resíduos e de geração de energia a partir de biomassa por eles aplicado. Além da visita, foram entrevistados o Engenheiro presidente do consórcio, e o Engenheiro responsável pela operação da estação.

Tal consórcio foi selecionado por representar um diferencial com relação à gestão dos sistemas municipais, com foco em tratamento de resíduos (em escala reduzida, quando comparado à geração de energia na Brescia). O foco da visita e entrevistas realizadas foi na gestão dos resíduos urbanos. 
Na entrevista foram descritos o sistema de seleção e descarga de resíduos, os cuidados tomados na gestão dos resíduos, as estratégias utilizadas pela empresa, e as campanhas de conscientização para os cidadãos para que estes colaborem com a coleta seletiva. Também foi descrita a utilização de biogás gerado a partir de resíduos verdes para gerar energia elétrica para utilização no funcionamento da estação (impianto). Os entrevistados destacaram que a energia restante ainda é vendida à rede para alimentação do município.

Ainda assim, observou-se, na entrevista com o presidente do Consórcio uma profunda sabedoria e prudência com relação à gestão de resíduos urbanos, e uma clara manifestação a favor do termoutilizador de Brescia, o que pretende implantar no futuro para a província de Alessandria.

O Consórcio preocupa-se em envolver os cidadãos na colaboração com a coleta seletiva, já que os materiais recicláveis podem ser vendidos, revertendo em renda para o consórcio, o que reduz as tarifas para os cidadãos. Como ainda usam aterro sanitário, isto também reduz a quantidade de lixo ali jogado, além dos benefícios naturais da reciclagem de materiais. São feitas fortes campanhas de conscientização com os cidadãos, gastam em torno de 30.000 Euros por ano, só com campanhas, incluindo material impresso e mídia. Eles também fretam ônibus e pagam o combustível para que sejam feitas visitas escolares às estações de tratamento de resíduos.

Após a entrevista foram efetuadas visitas à estação de seleção e tratamento de resíduos recicláveis, e à estação de tratamento de resíduos provenientes da coleta indiferenciada, à estação de geração de eletricidade a ao aterro sanitário, todas localizadas na cidade de Tortona, na Província de Alessandria.

O material documental recebido durante a visita foi publicação com divulgação e explicação sobre reciclagem, utilizado para conscientização da população e calendário de coleta.

Durante a visita, foi realizado registro fotográfico sobre o tratamento do lixo reciclável realizado, como forma de descrição do processo. As figuras 4 a figura 9 mostram este registro fotográfico.
Figura 4: Baias de recebimento do material; os cidadãos podem descarregar lixo volumoso, como grandes eletrodomésticos, na 'llha Ecológica.

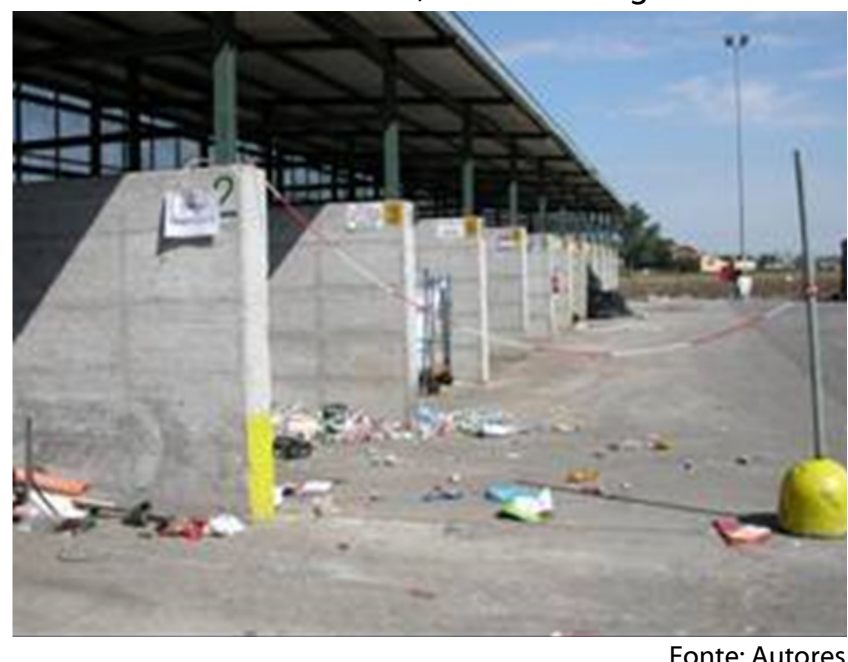

Figura 5: Recebimento de remédios vencidos e pilhas. Os remédios são incinerados.

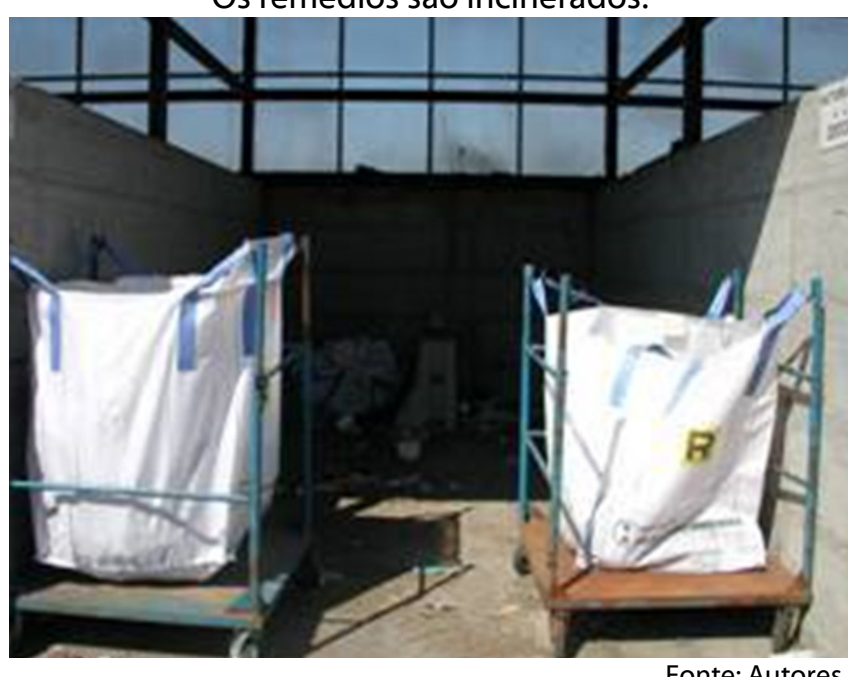

Figura 6: Separação de galões de plástico. São tratados em separado dos demais plásticos por terem eventualmente contido substâncias químicas ou óleoseletrodomésticos, na 'llha Ecológica.

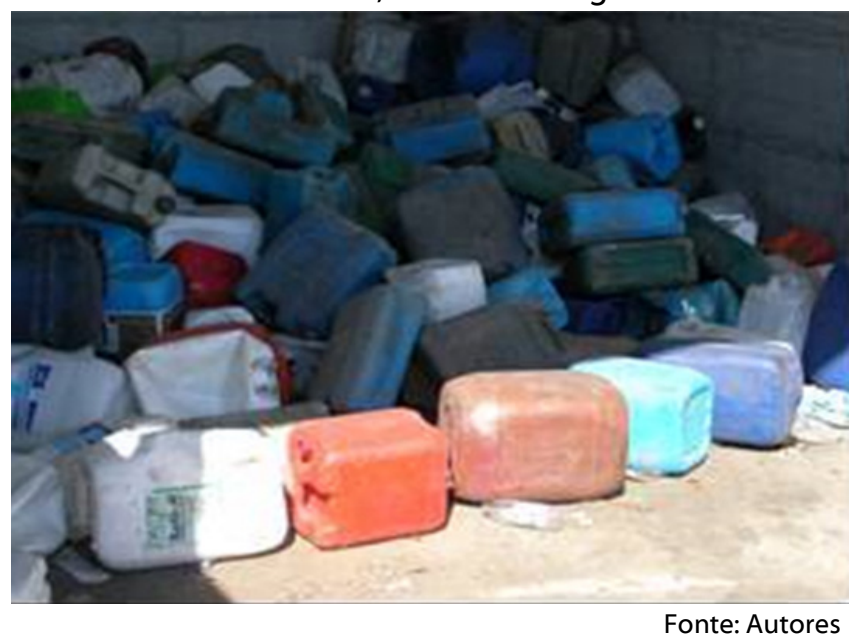


Figura 7: Separação de papel e papelão: é feita manualmente por tipo de material, sendo este colocado nas aberturas, caindo em esteiras para posterior empacotamento.eletrodomésticos, na 'llha Ecológica.

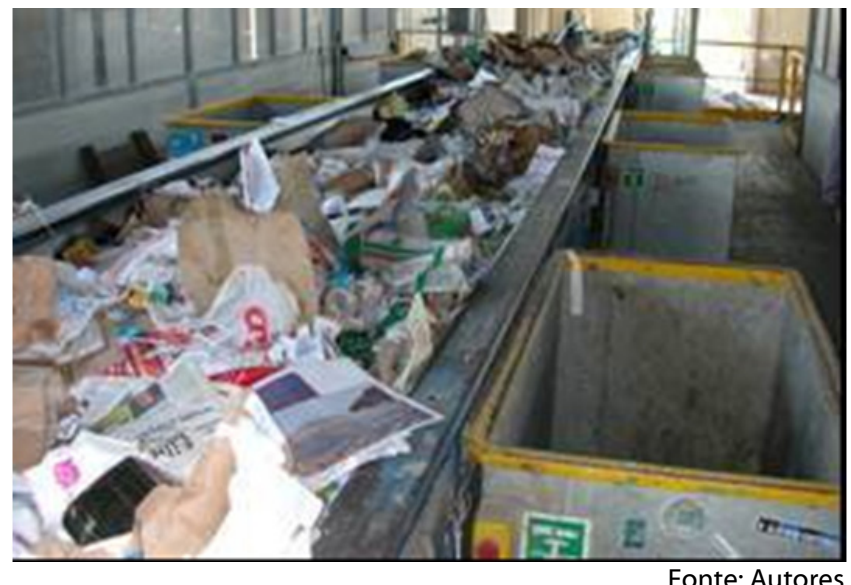

Figura 8: Empacotamento do plástico.eletrodomésticos, na 'llha Ecológica.

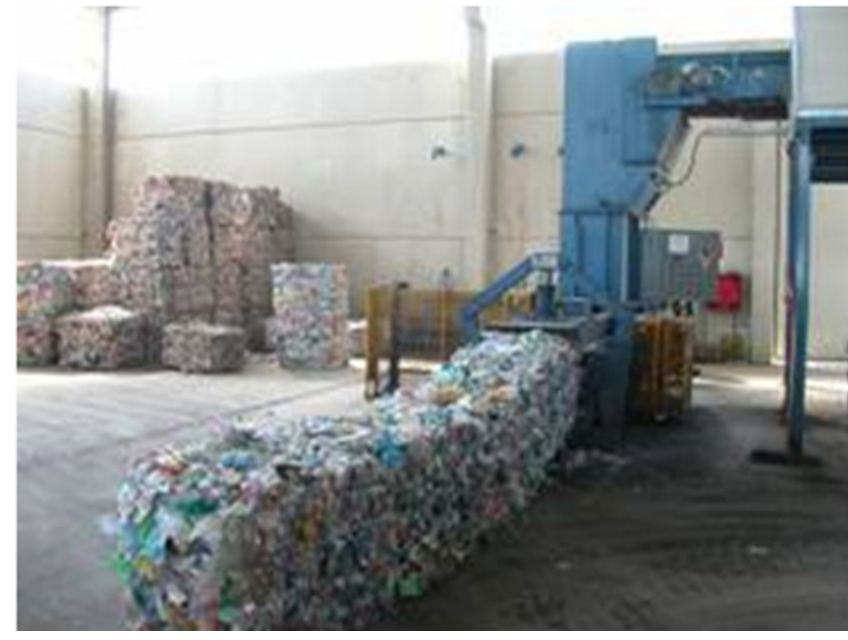

Fonte: Autores

Figura 9: Containeres com eletrodomésticos e monitores, a serem encaminhados para tratamento específico por terceiros.eletrodomésticos, na 'llha Ecológica.

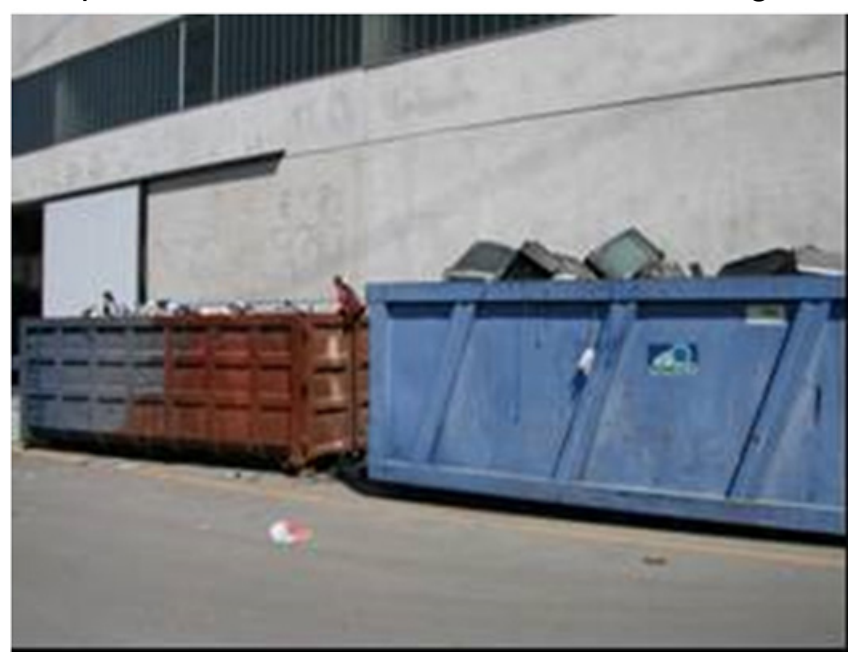

Fonte: Autores
A figura 10 à figura 13 mostram o registro fotográfico sobre o tratamento realizado para o lixo indiferenciado. $O$ destaque para este registro é a deposição do material resultante da coleta indiferenciada em um aterro sanitário especial. $O$ lixo estabilizado é depositado e acontece como na figura 13: o metano é captado, e gera biogás, que gera a eletricidade necessária para o funcionamento do complexo, e pequeno adicional para o uso pela população.

\subsection{ASMT - AZIENDA SERVIZI MUNICIPALI TOR- TONA}

Conectada com a etapa anterior, foi realizada visita a uma das empresas que prestam serviço para o consórcio (Consorzio Servizi Rifiuti), a ASMT, também localizada na cidade de Tortona. Durante a visita foi explanado pelo responsável pelo setor de aquisições o sistema de coleta seletiva realizado pela empresa.

Tal sistema é bastante exemplar. A empresa fornece lixeiras para cada tipo de resíduo a ser coletado: lixeiras para a coleta porta a porta (cada residência recebe uma lixeira marrom para resíduos orgânicos, cinza para coleta indiferenciada, e verde para restos de corte de grama e plantas (biomassa). Um calendário de coleta é distribuído aos moradores, com dias certos para coleta de cada tipo de resíduo. Assim, a empresa solicita que os moradores coloquem do lado de fora de casa a lixeira da cor definida, no dia definido. Para coleta de vidro, plástico, tetrapak, alumínio e papel e papelão, são colocadas nas ruas grandes lixeiras (containeres) de plástico de cores específicas, a uma distância máxima de 150 metros de cada residência.

De acordo com o entrevistado, em função desta organização e das campanhas de conscientização, no último ano atingiu-se um crescimento de coleta seletiva (que inicialmente era de $10 \%$ do lixo produzido na região), chegando a $40 \%$, e em algumas cidades até $70 \%$.

Durante a visita foram coletados folders de conscientização; adesivos explicativos para as lixeiras; lixeira doméstica com trava para lixo orgânico (amostra).

Durante a visita, foi realizado registro fotográfico sobre distribuição das lixeiras e coleta. A figura 14à figura 19 mostram este registro. 
Figura 10: Tratamento de resíduos da coleta indiferenciada.

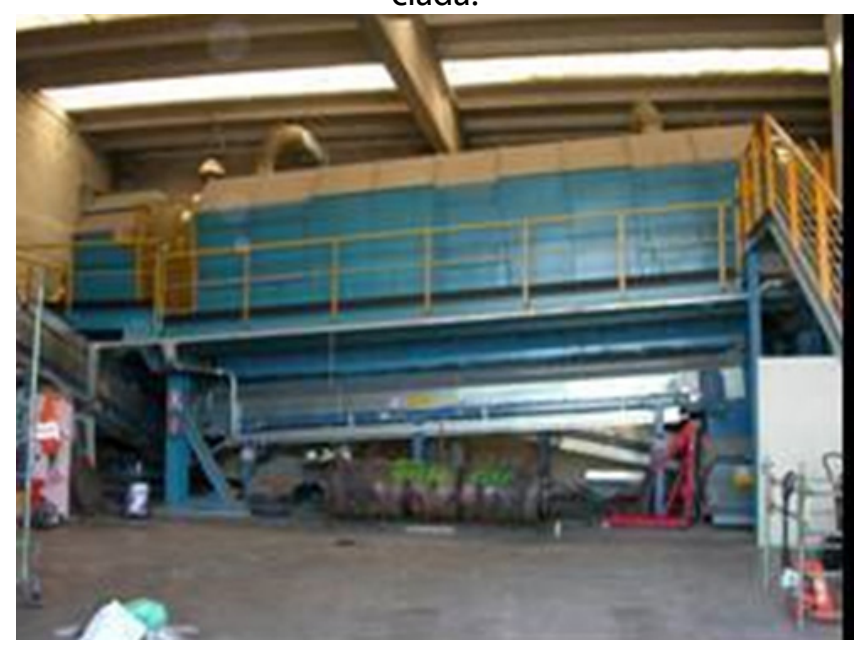

Fonte: Autores

Figura 11: Biofiltro para filtragem do ar que sai de dentro da estação de tratamento.

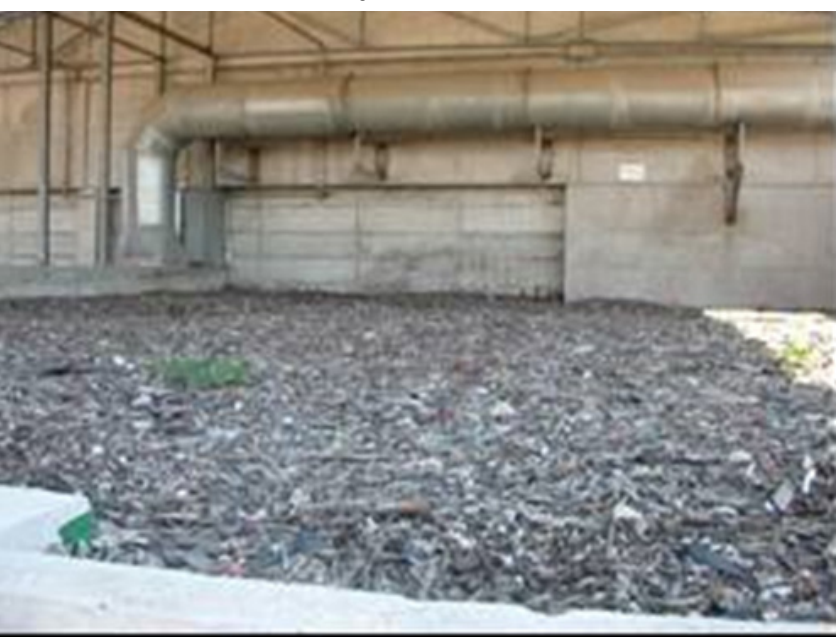

Fonte: Autores

Figura 12: Estabilização do lixo antes da deposição no

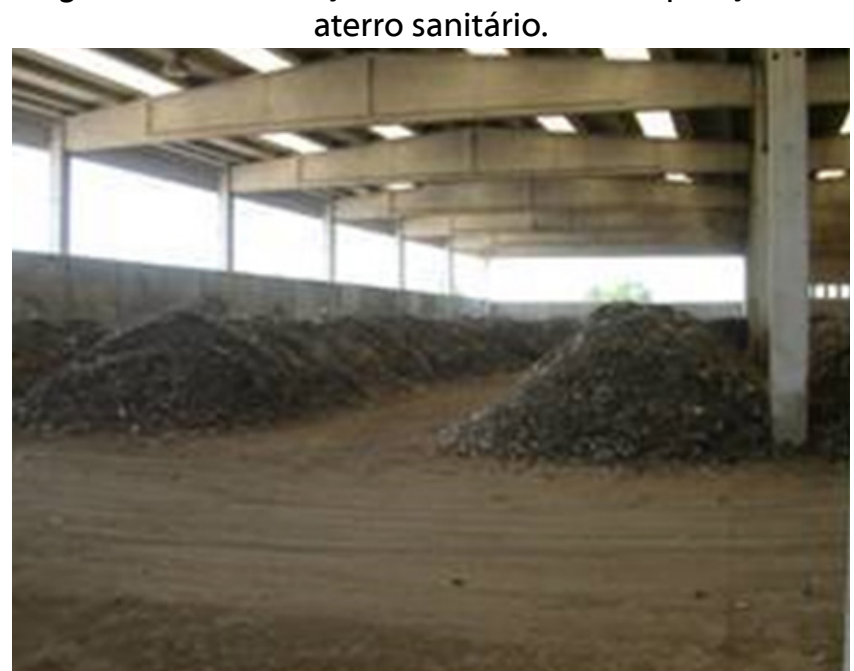

Fonte: Autores
Figura 13: Produção de biogás, que gera a eletricidade necessária para o funcionamento do complexo, e pequeno adicional para o uso pela população.

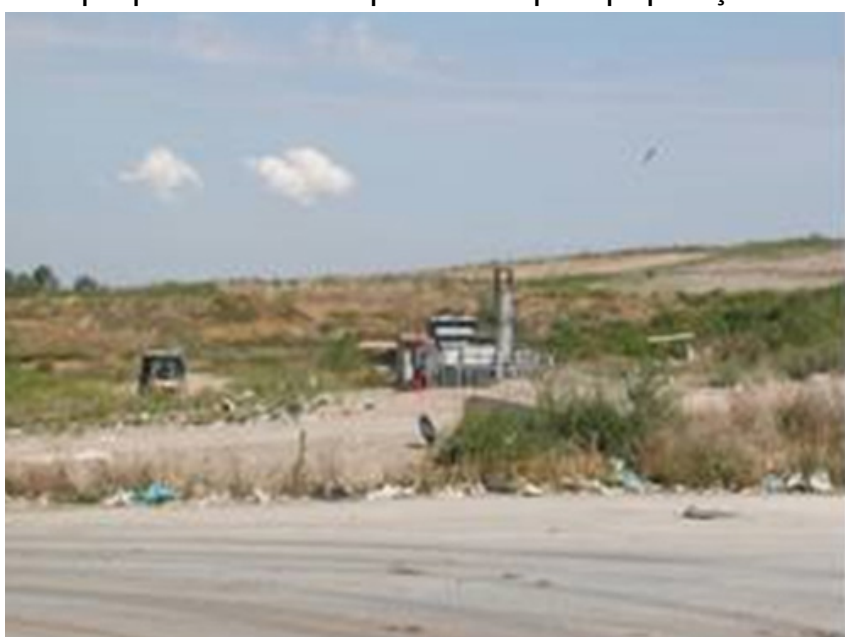

Fonte: Autores

Figura 14: Containeres de coleta de plástico, latinhas e tetrapak (amarela) e de papel e papelão (branca), posicionadas a cada 150 metros (máximo).

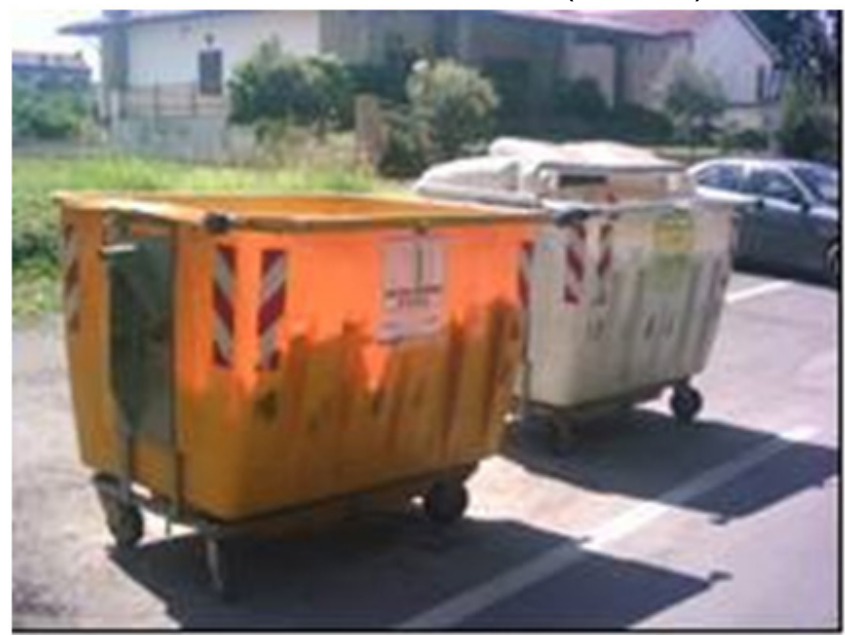

Fonte: Autores

Figura 15: Adesivos explicativos colados nas lixeiras, listando o que colocar ou não em cada uma.

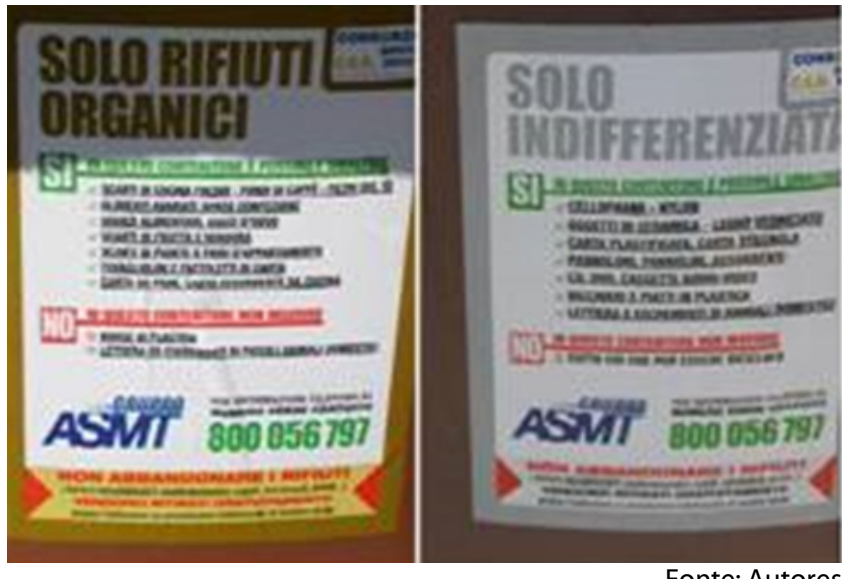

Fonte: Autores 
Figura 16: Lixeira para compostagem: cada residência pode ter a sua. O morador recebe o container, as instruções e os produtos para efetuar a compostagem de seus resíduos orgânicos.

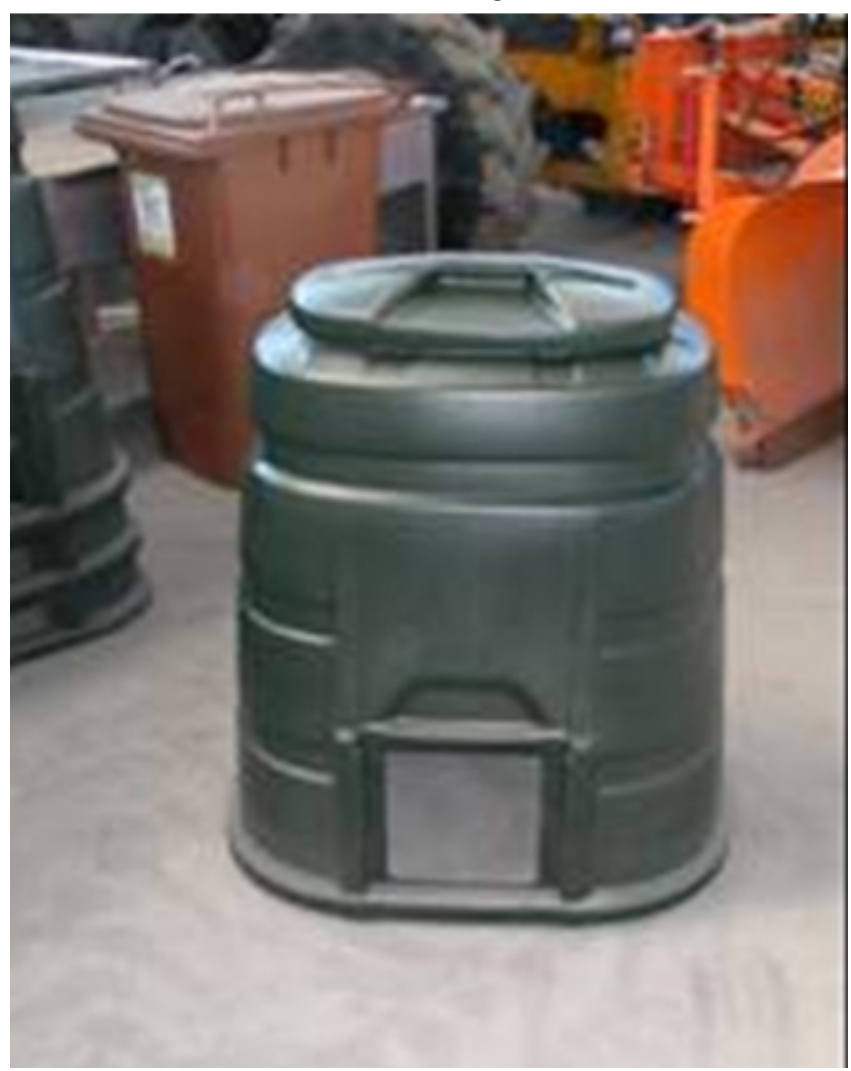

Fonte: Autores

Figura 17: Lixeira para comerciantes que trabalhem com alimentos (padarias, bares e restaurantes). Para evitar que toquem a lixeira, esta é provida de um dispositivo tipo chave, que quando encaixado abre a tampa da lixeira, e quando retirado a fecha.
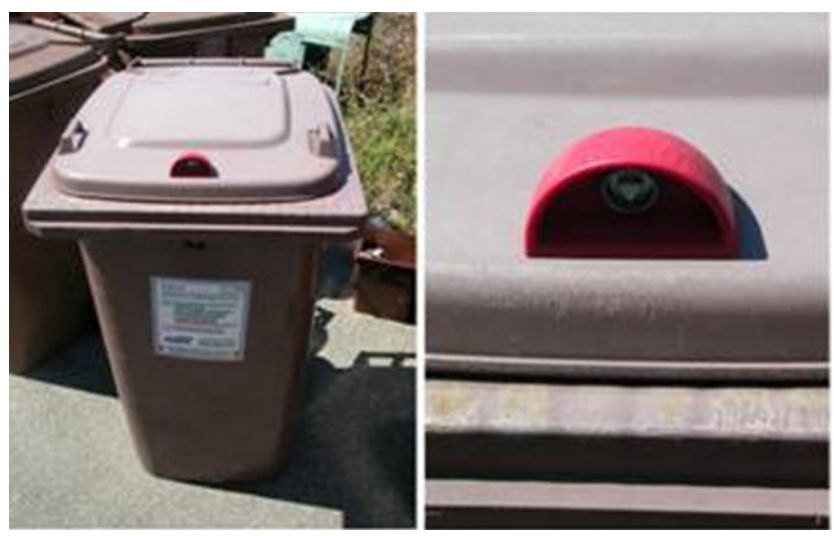

Fonte: Autores
Figura 18: Lixeira doméstica contendo resíduos orgânicos, colocada na frente de residência no dia específico da coleta.

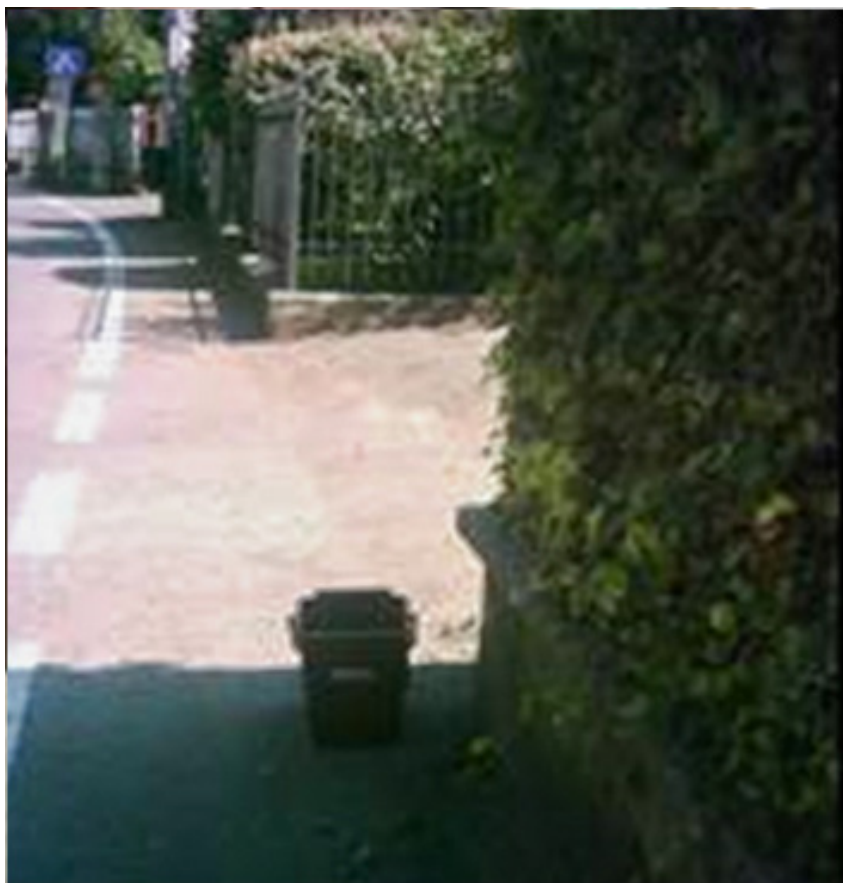

Fonte: Autores

Figura 19: Pátio do depósito da ASMT. Novos containeres a serem distribuídos em novos municípios, para a ampliação da coleta.

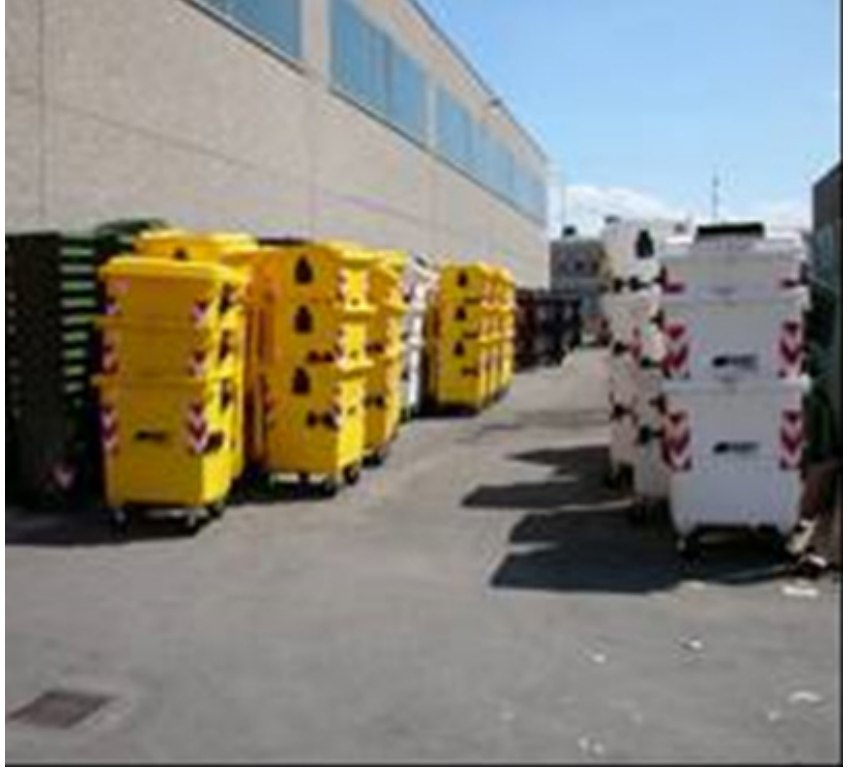

Fonte: Autores 


\subsection{TU - TERMOUTILIZADOR DE BRESCIA}

Durante o estudo, pode-se verificar o funcionamento do TU da Brescia.

Ao complexo, são enviados:

- Resíduos Sólidos Urbanos, (RSU), ou seja todo aquilo que não pude ser recuperado através da coleta diferenciada da área da cidade de Brescia ;

- Resíduos Especiais de atividades comerciais; etc.)

- Biomassa (madeira, resíduos vegetais,

A quantidade de resíduos e biomassa utilizados em um ano corresponde a 800.000 toneladas.

O poder calorífico dos resíduos oscila entre 1800 e $2400 \mathrm{kcal} / \mathrm{kg}$ dependendo da composição dos resíduos.

Um esquema do Termoutilizador da Brescia pode ser observado na figura 20:

No esquema de figura 20 são mostradas as fases da queima dos resíduos urbanos provenientes da coleta seletiva. Os resíduos, depois de passarem através de vários seletores (portais de monitoramento) para eliminar metais ou componentes perigosos, como substâncias radioativas (resíduos de hospitais, por exemplo), são descarregados em uma área fechada dividida por $2 / 3$ pela coleta de resíduos urbanos e pelo restante $1 / 3$ para a biomassa (pontos 1 e 2 em Figura 3).

Grandes gruas carregam os resíduos sobre uma grelha inclinada móvel (chamadas de Inclined Counter-Rotatig Grates, formadas de 15 degraus em movimento para cima que permitem uma melhor e contínua mistura dos resíduos para uma combustão total e eficiente, ponto 6 em figura 20) onde são queimados a uma temperatura de $1100{ }^{\circ} \mathrm{C}$ para assegurar a degradação das substâncias orgânicas tóxicas. Queimadores (Martin) adicionais são usados no caso que a combustão não possa ser sustentada à temperatura requerida (ponto 8 em figura 20).

Os gases quentes trocam energia (calor) com água produzindo vapor pressurizado a alta temperatura $\left(460^{\circ} \mathrm{C}\right.$, ponto 12 figura 20) que é usado, entre outros, para mover turbinas pela produção de energia elétrica ou para o aquecimento de edifícios. Os gases agora a temperatura de cerca de $200{ }^{\circ} \mathrm{C}$ são canalizados para filtros de depuração e resfriados para ser devolvidos à atmosfera. Os resíduos da combustão, sobre a grelha são resfriados lentamente para evitar, de novo, a formação de compostos pe-

Figura 20: Esquema do TU de Brescia.

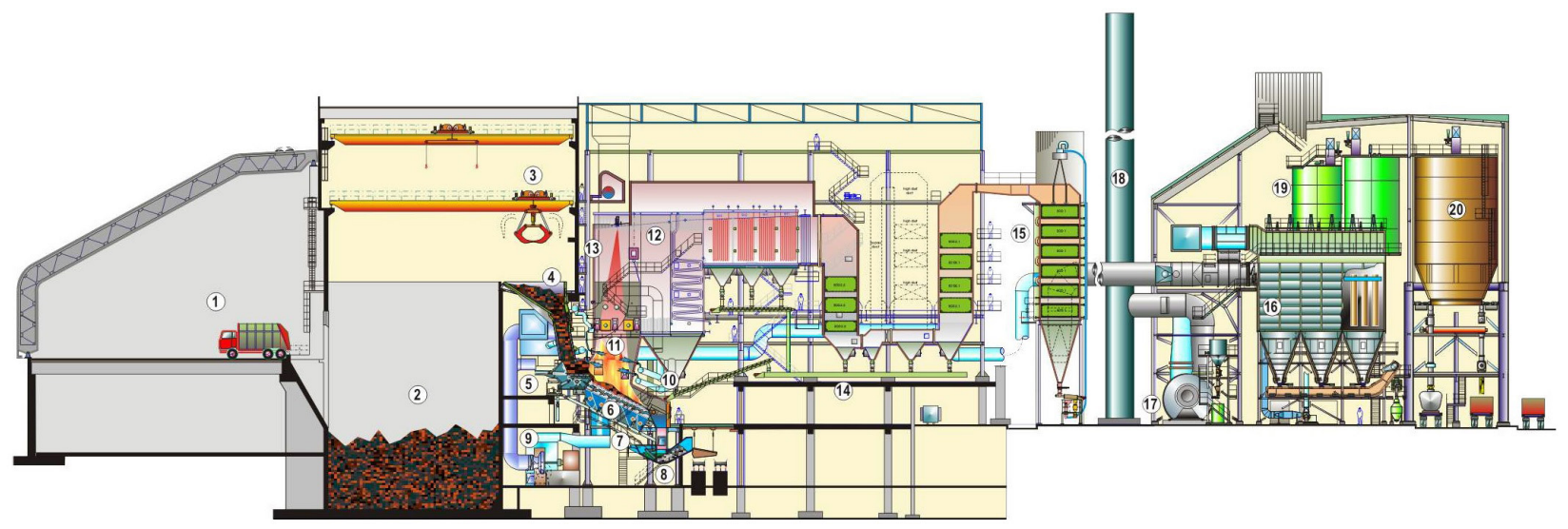

Fonte: MARTIN GmbH, (2007).

${ }^{3}$ Com composição típica: papel e papelão 35\%. Matérias plásticas 22\%. Material orgânico, tecidos e madeira 33\%. Material inerte, metal, vidro 10\% (em 2010 na área da prefeitura de Brescia).
${ }^{4}$ Quilocaloria (kcal) é a quantidade de calor necessário para levar $1 \mathrm{~kg}$ de água de $14,5^{\circ} \mathrm{C}$ até 15,5 ${ }^{\circ} \mathrm{C}$ á pressão de uma atmosfera. 
rigosos.

Escombros de metal de várias dimensões são retirados utilizando um eletro-imã e aviados para ser re-fundidos e o metal ser reutilizado.

$O$ incinerador produz como resultado da combustão:

1.Cinzas: estas são os resíduos sólidos da combustão que podem conter substâncias potencialmente tóxicas (metais pesados como cádmio, zinco e chumbo).

2.Gás: são produzidos pela destruição, através combustão, de moléculas orgânicas altamente complexas (como borrachas) ou pela vaporização de substâncias normalmente inertes (mercúrio) e podem conter novas substâncias altamente tóxicas (dioxina, $\mathrm{CO}_{2}, \mathrm{SO}_{2}, \mathrm{NOx}$ ).

3.Calor, com uma energia térmica produzida anual de 505 milhões de quilowatt-hora.

No teleriscaldamento a água é aquecida pelo calor produzido na queima dos resíduos e enviada pela rede de aquecimento da cidade (figura 21). Na entrada de cada residência ou prédio há uma central que regula a entrada de água quente e devolve aquela já fria, após a passagem desta pelos radiadores nas residências. A água volta ao TU para ser novamente aquecida e continuar o ciclo (figura 21).

Junto com a redução de poluição devido à eliminação do aquecimento tradicional necessário nos edifícios o TU, produzindo energia elétrica, contribui para a redução de poluição devida à produção clássica de eletricidade (centrais termoelétricas).

Em 2008, o TU de Brescia produziu e injetou na rede: 569 GWh de energia elétrica e 574 GWh de energia térmica. Em 2009 a produção e injeção na rede pelo TU foi $430 \mathrm{GWh}$ de energia elétrica e 615 GWh de energia térmica. Em 2010, o TU produziu e injetou na rede: $575 \mathrm{GWh}$ de energia elétrica e $796 \mathrm{GWh}$ de energia térmica. Aenergia elétrica oscilou, mas a produção de energia térmica só cresceu.

Para atender aos limites de emissões estabelecidos pelas leis de cada país o processo de combustão deve ser controlado corretamente e os gases de combustão limpos antes de sua vazão final (Figura 22).

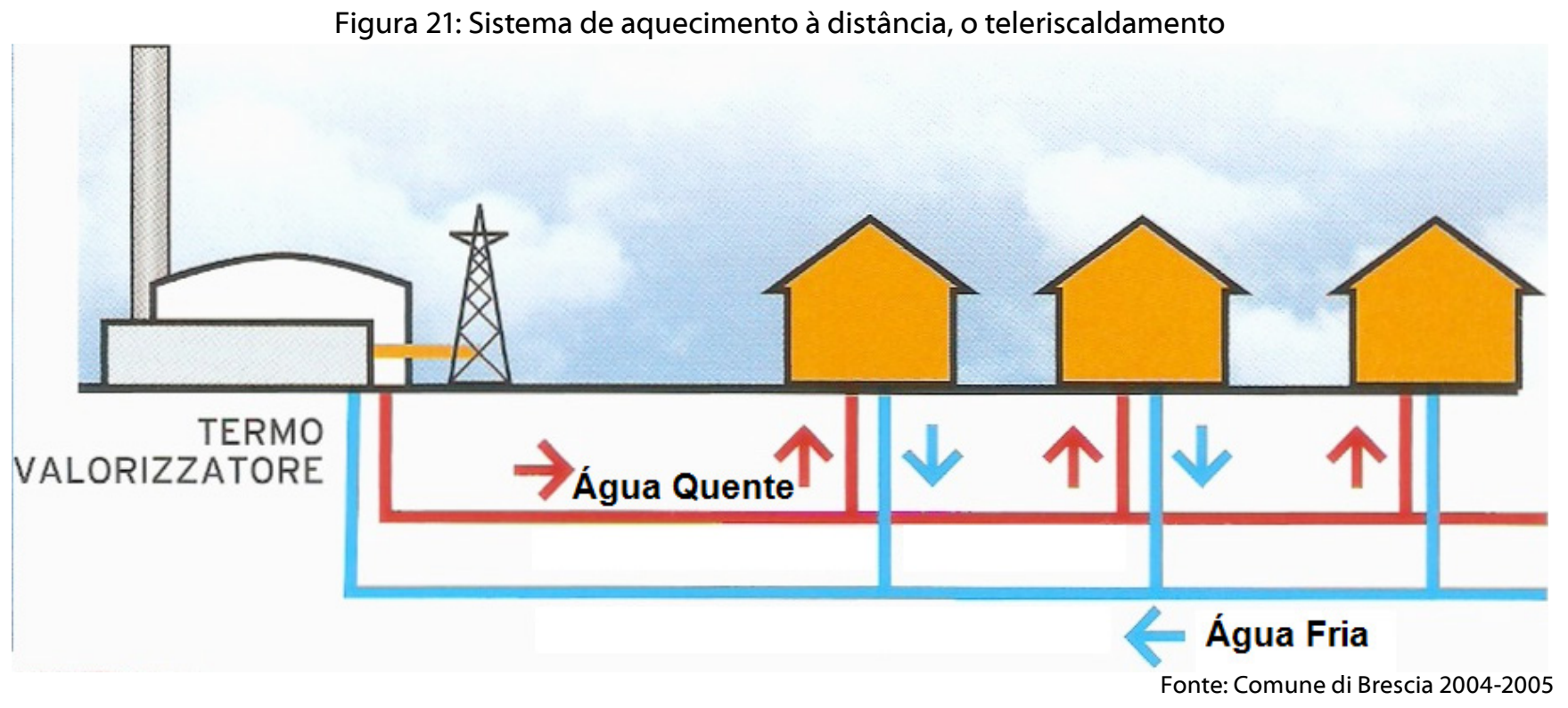


Figura 22: Comparação entre as emissões do TU e os limites estabelecidos pela lei.

\section{EMISsIONS}

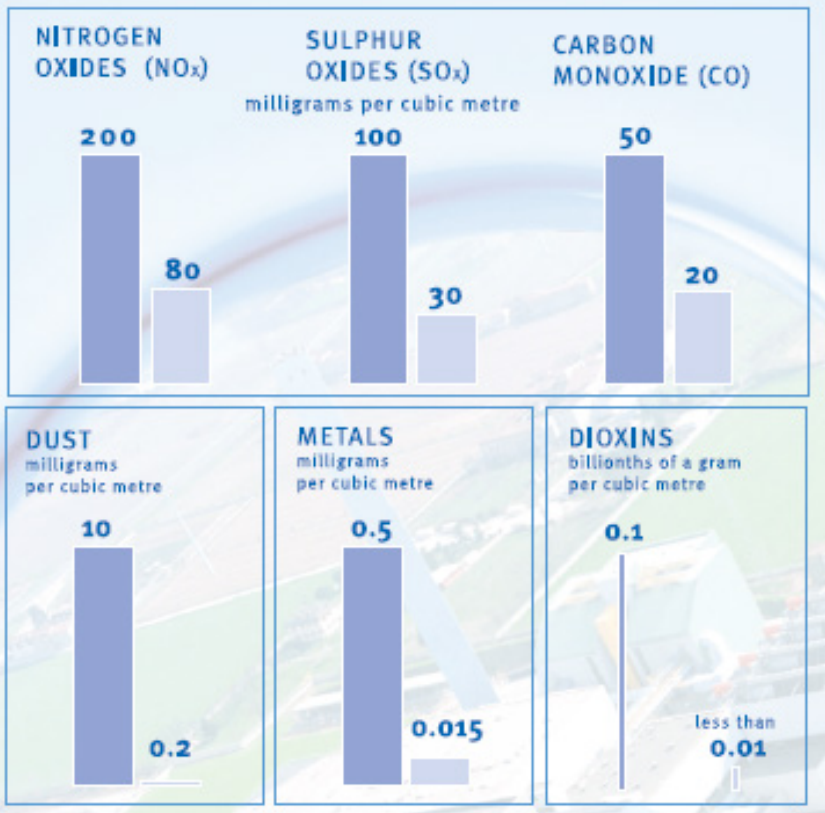

EMISSION LIMITS (M.D: 503/97)

READINGS TAKEN AT THE WASTE-TO-ENERGY PLANT IN BRESCIA

(Fonte: Comune di Brescia 2008-2010)

O controle do produto final depois das fases de filtragem é executado na chaminé a várias alturas com equipamentos de monitoramento que continuamente medem a concentração de:

- Oxigênio $\left(\mathrm{O}_{2}\right)$;

- Monóxido de Carbono (CO);

- Dióxido de Enxofre $\left(\mathrm{SO}_{2}\right)$;

- Óxidos de Nitrogênio $\left(\mathrm{NO}_{\mathrm{x}}\right)$;

- Acido Clorídrico ( $\mathrm{HCl})$;

- Pós Totais em Suspensão (PTS);

- Carbono Orgânico Total (COT).

O sistema de monitoramento contém aparelhos duplos para manter continuidade de monitoramento mesmo em caso de falha.

Durante a visita ao TU, recebeu-se: (1) DVD de apresentação do termoutilizador; (2) Relatório do observatório sobre o funcionamento do termoutilizador referente aos anos de 2004 e 2008; (3) Material explicativo sobre a geração de energia e teleriscaldamento; (4) Livro com a história da empresa ASM, e da implantação dos serviços municipais na Brescia.
O registro fotográfico realizados durante a visita ao TU é apresentado nas figura 23 a figura 28.

Figura 23: Vista externa do termoutilizador.

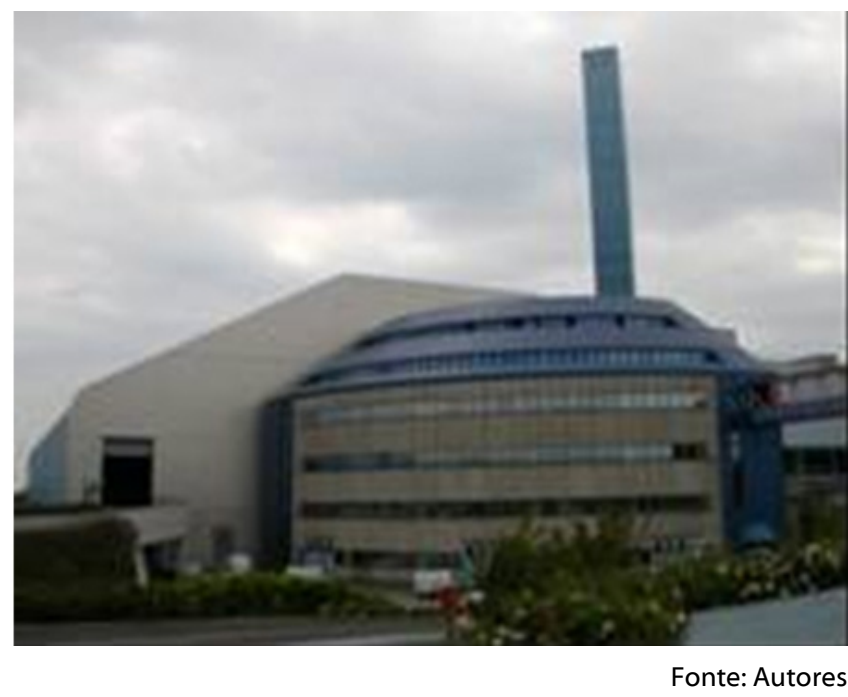

Figura 24: Chaminé contra o céu no período da manhã; vista de alguns ângulos, é quase invisível (baixo impacto visual).

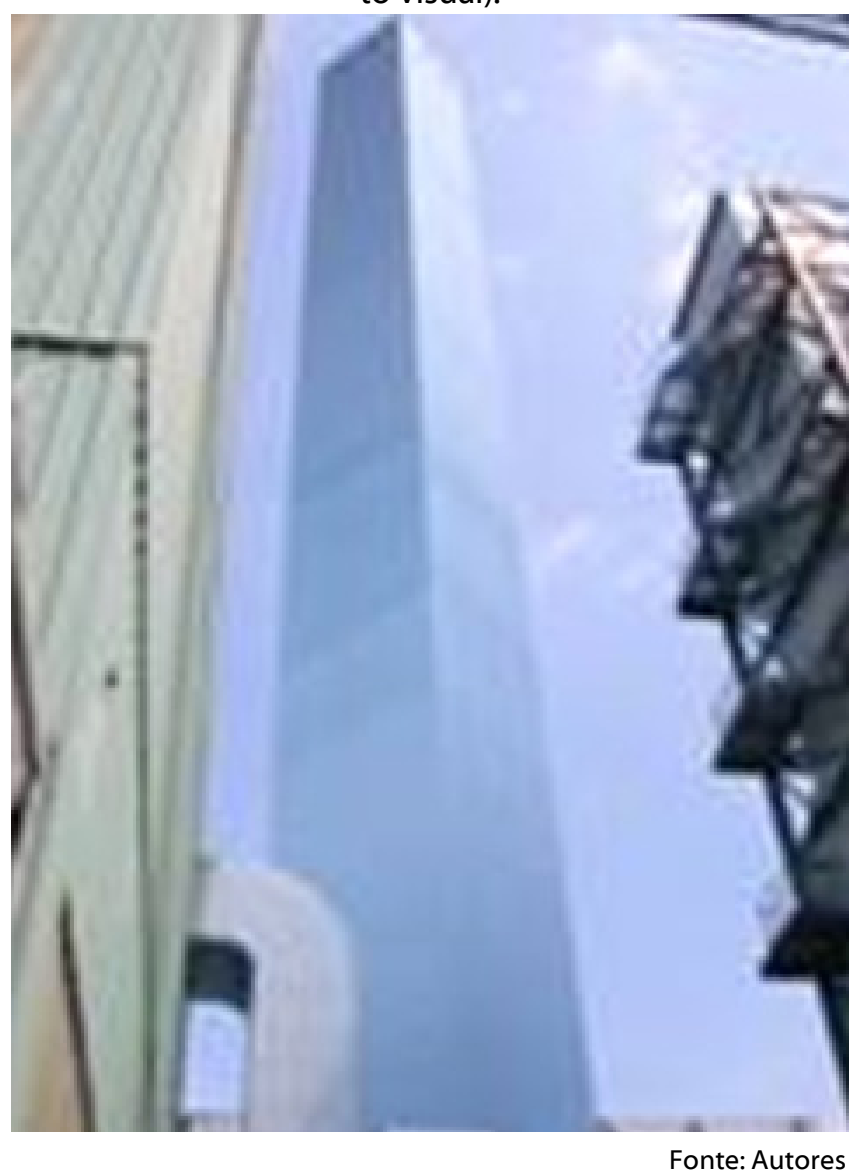


Figura 25: Portal pelo monitoramento dos resíduos perigosos (radioativs).

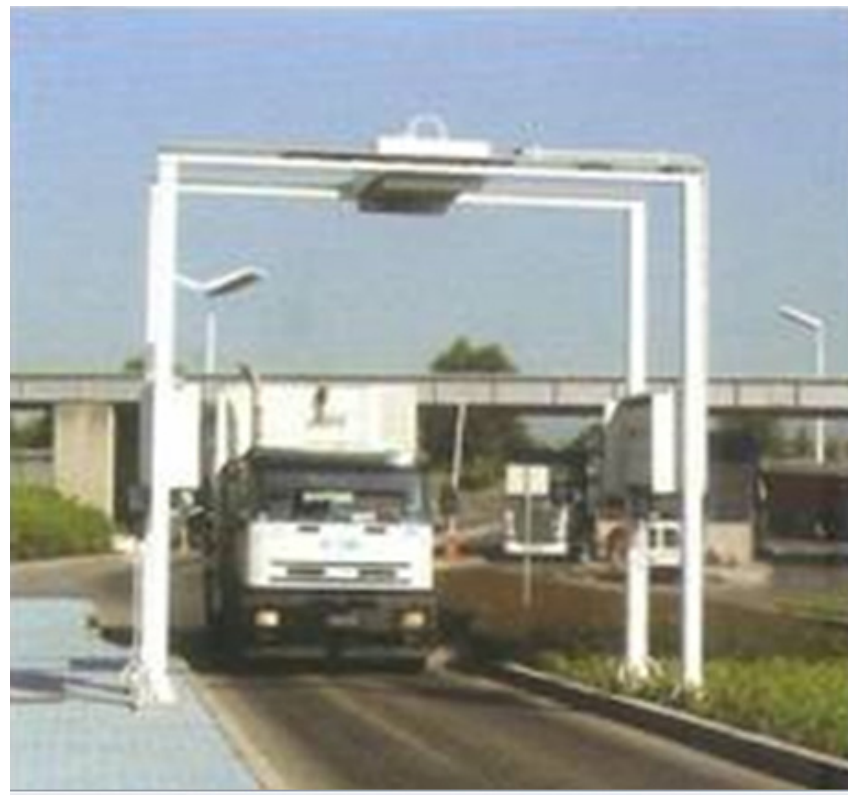

Fonte: Autores

Figura 26: Área fechada de coleta dos resíduos.

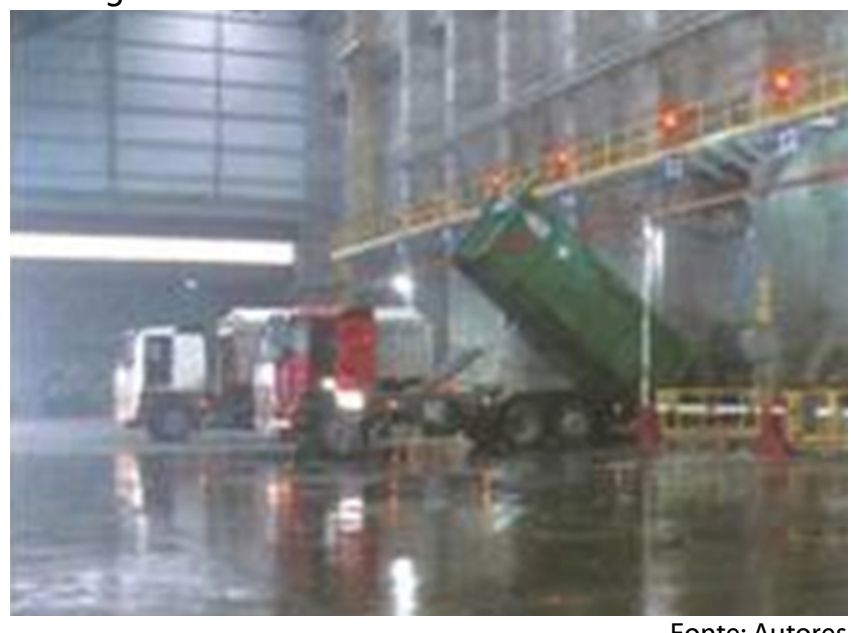

Figura 27: Queimadura dos resíduos na grelha inclinada móvel.

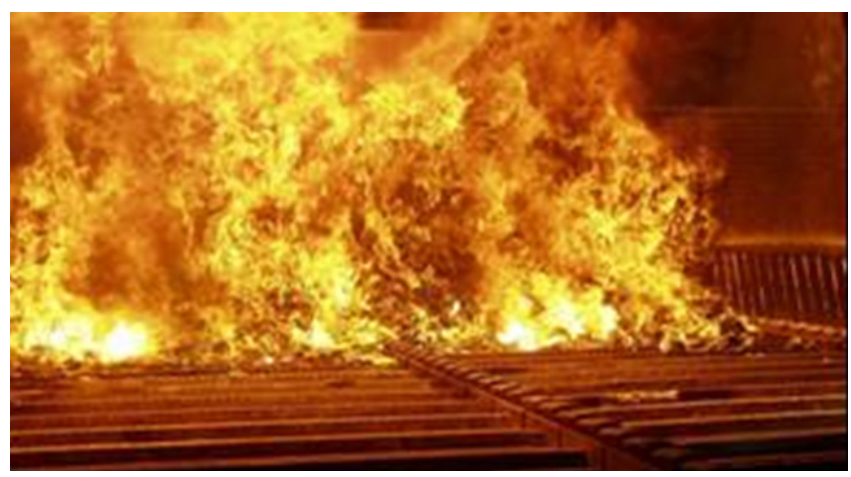

Fonte: Autores
Figura 28: Resultado da incineração: metais e escória

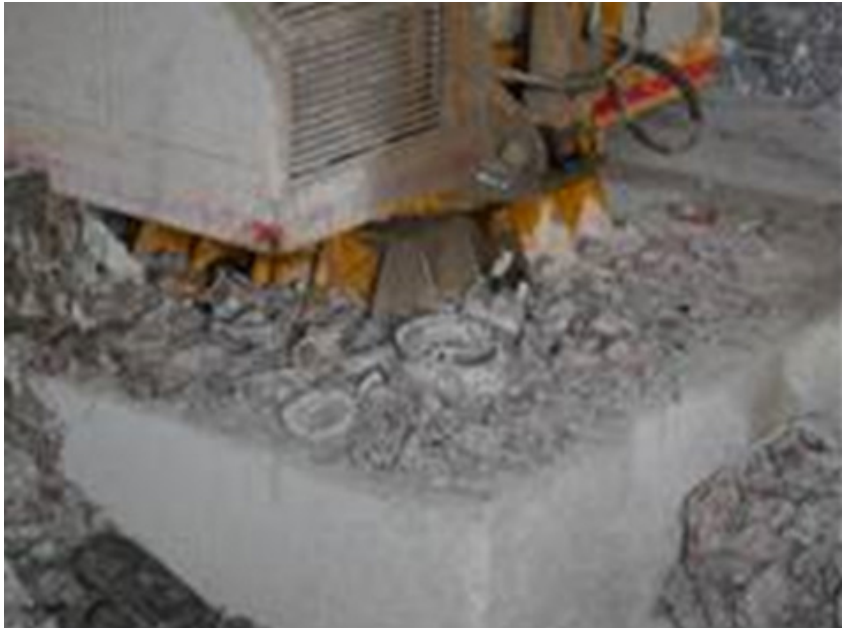

Fonte: Autores

\section{CONCLUSÕES}

Considerando a experiência adquirida no estudo relatado neste artigo, pode-se concluir que a coleta seletiva pode ajudar a: reduzir a necessidade de matérias primas; reduzir consumo de água e energia; reduzir o volume e controlar a tipologia dos resíduos destinados ao armazenamento (aterros); proteger o ambiente e a saúde humana (evitando depositar sobre o território materiais direta ou indiretamente perigosos).

Em conclusão o uso de sistemas de coleta seletiva com combinada geração de energia como no caso do TU, pode gerar uma redução consistente do espaço ocupado pelos resíduos e da conseqüente poluição gerada pelos mesmos. Em conjunção, este tipo de tecnologia produz como efeito secundário energia que pode ser utilizadas em substituição aquela produzida com métodos convencionais altamente poluentes (combustíveis fósseis, nuclear, etc).

A oposição a este método de eliminação de resíduos vem principalmente do medo da periculosidade dos gases produzidos durante a combustão. Mas grande parte do complexo do TU é dedicada exatamente ao controle e eliminação destes gases. A grande diferença com os métodos tradicionais de eliminação de resíduos e que esta técnica permite o monitoramen- 
to pontual e passo a passo de todas as fases do processo de eliminação dos resíduos.

O impacto sobre o território da presença do TU pode também ter características positivas e negativas em relação à aceitação do público. Normalmente a percepção do público à presença de um TU sobre o território tende a ser negativa por causa de razões relacionadas às emissões, mal cheiro, pó, barulho e estrago da paisagem. Porém, a maioria destas razões é conectada com os métodos de operação de velhos incineradores com tecnologias antigas e controles quase inexistentes. Hoje em dia os controles e as leis que regulam as emissões são rigorosos.

Pode-se, então concluir que a coleta seletiva proporciona uma redução no uso de matérias primas e de energia e pode operar em conjunto com o TU, representando uma tecnologia de baixo impacto ambiental do ponto de vista das emissões e visual produzindo, em complexo, benefícios pela comunidade. Tais benefícios aparentam serem superiores às desvantagens da presença do complexo no território da região.

\section{REFERÊNCIAS}

\section{A2A. http://www.a2a.eu/gruppo/cms/a2a/}

ASMT. Azienda Servizi Municipali Tortona. www.asmt.it

Barbosa, V. Até quando Brasil vai enterrar seus resíduos em lixões? Revista Exame, Editora Abril S.A., 2014.

BRASIL. Lei 12.305 - Institui a Política Nacional de Resíduos Sólidos; altera a Lei no 9.605, de 12 de fevereiro de 1998; e dá outras providências, 2 de agosto de 2010 .

COMUNE DI BRESCIA Settore Ambiente ed Ecologia. Rapporto dell'osservatorio sul funzionamento de Termoutilizzatore di Brescia relativo agli anni 2004-2005 e 2008-2009-2010.

COMUNE DI BRESCIA. Termoutilizzatore. Dis- ponível em: http://www.comune.brescia.it/ Istituzionale/Settori/ambiente+ed+ecologia/ termoutilizzatore.htm. Acesso em abril de 2008.

CONSORZIO SERVIZI RIFIUTI. Disponível em: http://www.csrifiuti-noviligure.it/index.php

ECO DALLE CITTA. Notiziario per l'ambiente urbano e l'ecologia. Disponível em: http://www. ecodallecitta.it/notizie/11406/ecobank-successo -ad-alessandria-per-la-macchina-che-da-2-centesimi-a-bottiglia/ acesso: maio 2015

EPA - U.S. Environmental Protection Agency. Marine Debris in the North Pacific A Summary of Existing Information and Identification of Data Gaps. 2011

MARTIN GMBH, Thermische Abfallbehandlungsanlage ASM Brescia, Italien - Waste-to-Energy Plant ASM Brescia, Italy. 2007

MARTIN GMBH, Thermische Abfallbehandlungsanlage ASM Brescia, Italien - Waste-to-Energy Plant ASM Brescia, Italy. 2007

OGGI. Revista do Corrieri Della Sera. Por Alessandro Pena. Milão, Janeiro de 2008. P. 26-29.

PARO, A., C., da Costa, F., C., Coelho, S. T. Estudo Comparativo para o tratamento de Resíduos Sólidos Urbanos: Aterros Sanitários $\mathrm{X}$

ROBERTS, R., J., Chen, M. Waste incinerationhow big is the health risk? A quantitative method to allow comparison with other health risks. Journal of Public Health, Vol. 28, No. 3, pp. 261-266 (doi:10.1093/pubmed/fdl037 Advance Access Publication 25 July 2006).

SISINNO, C., L., S., Moreira, J., C. Avaliação da contaminação e poluição ambiental na área de influência do aterro controlado do Morro do Céu, Niterói, Brasil. Cad. Saúde Públ., Rio de Janeiro, 12(4):515-523, out-dez, 1996 